\title{
Peluang dan Tantangan Pemerolehan Bahasa Arab sebagai Bahasa Kedua (Kajian Psikolinguistik Pada Pembelajaran Bahasa Arab)
}

\author{
Nurul Hidayah \\ UIN Raden Fatah Palembang \\ email: nurulhidayah@radenfatah.ac.id
}

\begin{abstract}
Abstrak
Bahasa kedua sering dibedakan dengan istilah bahasa asing. Alasan utamanya adalah bahasa asing cendrung jarang digunakan dalam keseharian pembelajar, tidak seperti bahasa kedua yang tentunya akan digunakan pembelajar dalam kesehariannya. Bahasa kedua untuk pembelajar Indonesia adalah bahasa Indonesia, sedangkan bahasa asing yang digelutinya diantaranya adalah bahasa Arab. Permasalahan muncul ketika bahasa asing juga digunakan dalam keseharian Pembelajar seperti di beberapa sekolah yang memiliki system boarding school. Sekolah ini biasanya akan membuat sebuah wadah yang akan memfasilitasi Pembelajar bahasa agar bisa menggunakan bahasa yang mereka pelajari ke dalam bahasa kesehariannya. Jika dilihat dari fenomena tersebut maka sebenarnya sekolah tersebut sedang membuat suasana pembelajaran bahasa asing agar bisa memiliki sebuah proses layaknya proses pemerolehan bahasa. Sebagaimana proses pemerolehan bahasa pertama, pemerolehan bahasa kedua juga dipelopori dengan kemampuan menyimak. Hal ini tentunya didasari oleh fitrah manusia yang lebih dahulu memiliki kemampuan tersebut dibanding kemampuan berbahasa lainya seperti berbicara, membaca dan menulis. Usaha pemerolehan bahasa kedua ini tentu saja akan memiliki peluang yaitu adanya lingkungan bahasa buatan bisa mengoptimalkan pemerolehan bahasa. Sedangkan tantanganya adalah adanya perbedaan bentuk dan penggunaan bahasa arab dibandingkan dengan bahasa Indonesia, sehingga pembelajar akan cendrung melakukan tiga kesalahan yaitu kesalahan interlanguage, intralanguage, dan kesalahan pada content kalimat.
\end{abstract}

Kata kunci: Pemerolehan Bahasa Arab, Kesalahan berbahasa

\section{PENDAHULUAN}

Bahasa adalah sebuah produk budaya manusia yang senantiasa terus berkembang seiring dengan perkembangan zaman. Karenanya kajian tentang bahasa seolah tak habis untuk dikaji baik dari segi konsep bahasa ataupun penerapan bahasa itu sendiri. Dalam ilmu bahasa, kita mengenal istilah universal grammar yang menyatakan bahwasanya setiap bahasa memiliki kemiripan dari segi tata bahasa, sehingga hal inilah yang disinyalir bisa membuat sesorang untuk menguasai lebih dari satu bahasa. 
Proses penguasaan terhadap sebuah bahasa terbagi menjadi dua yaitu proses pemerolehan dan proses pembelajaran bahasa. Kemudian akan muncul pertanyaan apakah kedua elemen ini bisa dilakukan dalam satu waktu ataukah keduanya adalah separated sistem yang tidak bisa dipadupadankan dalam bentuk sebuah system yang saling menyelaraskan?

Keselerasan system berbahasa sebagai sebuah modal seseorang untuk berkomunikasi adalah suatu hal yang hingga saat ini masih sulit dikembangkan, kajian Huda terkait model pemerolehan bahasa arab sebagai bahasa kedua menunjukkan bahwa bahasa arab masih menjadi bahasa asing dan bukan bahasa kedua, artinya ada sebuah postulat yang muncul bahwa bahasa arab akan sulit untuk diterapkan secara proporsional seperti bahasa kedua (Huda, 2017)

Namun penelitian Faiqoh terkait pemerolehan fonologi menunjukkan bahwasanya pemerolehan bahasa arab justru banyak terjadi di kelas bahasa bukan dilingkungn sekitar dimana pembelajar tersebut sedang berinteraksi sosial. (Faiqoh, 2014) Anshari juga menambahkan terkait pemerolehan gramatika dan rasa bahasa bisa dikatakan berhasil jika pembelajar tersebut mampu berinteraksi dengan baik bersama native speaker yang memiliki bahsa tersebut.(Anshari, n.d.)

Artikel ini mencoba untuk mengulas peluang dan tantangan yang akan dihadapi oleh para pembelajar bahasa, akankah sebuah bahasa asing mampu untuk menjadi bahasa kedua?, jika bahasa asing yang dalam hal ini adalah bahasa arab dijadikan sebagai salah satu bahasa yang digunakan dalam keseharian pembelajar? Akankah sebuah lingkungan buatan berbahasa arab mampu membuat bahasa asing menjadi bahasa kedua?

\section{KAJIAN TEORI}

Pengertian Pemerolehan Bahasa

Pemerolehan bahasa menurut Tarigan di dalam Thonthowi adalah sebuah proses yang dipergunakan oleh anak untuk menyesuaikan serangkaian hipotesis yang makin bertambah rumit, ataupun teori-teori yang masih terpendam atau tersembunyi yang mungkin sekali terjadi dengan ucapan-ucapan orang tua sampai dia memilih berdasarkan suatu ukuran atau takaran penlaian tata bahasa yang 
paling baik serta yang paling sederhana dari bahasa tersebut (Thonthowi, 2015, p. 32).

Adapun pemerolehan bahasa menurut Krashen dan dan Terrel sebagaimana dikutip Ainin, dapat dimaknai dengan pengembangan kemampuan bahasa secara alamiah dalam situasi yang komunikatif (Ainin, 2010). Dari kedua pengertian tersebut dapat dibuat kesimpulan bahwasanya pemerolehan bahasa adalah adanya penambahan pengetahuan terkait sebuah bahasa sehingga seseorang mampu memahami bahasa tersebut secara natural dan menggunakannya secara interaktif dengan orang disekitarnya.

Pemerolehan bahasa secara umum dibagi menjadi dua bagian yaitu pemerolehan bahasa pertama dan pemerolehan bahasa kedua. bahasa pertama adalah bahasa yang pertama kali didengar oleh setiap anak. Sesuai dengan fitrahnya anak akan meniru apa yang telah dia dengar untuk kemudian dilafalkan sebagai sebuah kata, frase ataupun kalimat dalam sebuah proses. Sedangkan bahasa kedua adalah bahasa yang diperoleh seseorang setelah dia melalui fase bahasa pertama. Selain bahasa kedua dikenal pula istilah bahasa asing.

Baik bahasa kedua maupun bahasa asing lebih didominasi dengan sebuah proses pembelajaran. Hal ini menunjukkan bahwa anak yang mempelajari kedua bahasa tersebut secara sadar mempelajarinya untuk dipergunakan. Sayangnya bahasa arab sampai saat ini masih termasuk kedalam kategori bahasa asing di beberapa sekolah, meskipun Sekolah yang berbasis boarding School sudah menyadur pemerolehan bahasa ini sebagai sebuah piranti untuk kemudian dioptimalkan dalam pemerolehan bahasa kedua.

\section{Pemerolehan Bahasa Pertama}

Secara umum proses pemerolehan bahasa pertama pada seorang anak dibagi menjadi dua yaitu proses yang disebut dengan kompetensi dan perfomansi. Kompetensi sebagai mana dikutip Hasanah merupakan proses seorang anak dalam memahami semantic, sintaksi dan juga fonologis sebuah kata yang telah diperolehnya dari orang terdekat yang ada di sekitarnya. Adapun perfomansi adalah sebuah proses aktualisasi bahasa dari seorang anak sehingga anak mampu 
menghasilkan kalimat tadi kedalam bentuk ujaran lisan ataupun kalimat tertulis (Hasanah, 2010).

Berdasarkan pembagian tersebut, maka setiap anak akan melakukan proses "pembekalan berbahasa” untuk kemudian dituangkan kedalam bentuk ucapan yang dalam hal ini disebut dengan perfomansi. Adapun proses berbahasa seorang anak dibagi menjadi beberapa fase yaitu, tahap mengoceh pada usia 3-6 bulan, produksi kata pertama yang difahami orang lain usia 6-9 bulan, produksi instruksi sederhana yang difahami usia 9-12 bulan, pelafalan kata pertama yang diucapkan usia 10-15 bulan, penambahan dan penerimaan kosa kata (usia 2 tahun, sekitar 300 kata) masa perkemabangan bahasa akan semakin pesat ketika usia anak sudah memasuki 3 tahun.(Hasanah, 2010)

Dilihat dari pembagian fase tersebut tepat kiranya jika kita menyatakan bahwasanya proses manusia memperoleh bahasa disamakan dengan proses perkembangan bahasa. Karena pemerolehan bahasa tentusaja membuat bahasa yang dimiliki seseorang akan berkembang sesuai dengan proses yang dialaminya.

Adapun Poerwo di dalam Chaer secara jelas membagi proses perkembangan bahasa kedalam dua pembagian yaitu perkembangan artikulasi dan perkembangan kata dan kalimat (Chaer, 2009). Pada perkembangan bahasa pertama anak mulai mengeluarkan bunyi-bunyi khusus sebagai respon terhadap keinginan dan rasa yang sedang dirasakan, kemudian dilanjutkan dengan perkembangan kata, lalu menjadi kalimat dan seterusnya.

Pemerolehan Bahasa Kedua

Pemerolehan bahasa kedua identik dengan pembelajaran bahasa yang dialami anak ketika berada di kelas. Namun beberapa pakar bahasa berbeda pendapat terkait hal tersebut. Swain, selingker, Dumas, Swain, Lapkin, Barik, Cohen, Plann di dalam Ghazali menyatakan bahwa pemerolehan bahasa kedua didukung penuh oleh keberadaan kelas bahasa yang tidak terpaku pada pengajaran kaidah berbahasa saja, namun menyediakan sesuatu yang dapat menjadi sumber anak dalam memperoleh bahasa kedua seperi layaknya pemerolehan bahasa pertamanya (Ghazali, 2013). 
Kelas yang menyediakan kondisi sebagaimana diatas tentunya harus memiliki daya tarik tersendiri, sehingga akan membuat anak yang telah memperoleh bahasa pertama akan bisa menyiapkan dirinya dari segi mental dan kognitifnya untuk menerima bahasa yang baru sebagai input yang nantinya akan diolah untuk diproduksi sebagai bahasa.

Pendapat ini dibantah oleh Ellis di dalam Ghazali, bahwasanya kelas yang menarik untuk mempelajari bahasa belum bisa dianggap sebagai piranti anak dalam memperoleh bahasa kedua selayaknya bahasa pertama. Di dalam kelas bahasa kedua harus lebih menekankan sebuah proses input yang bernama interaksi komunikatif antara pembelajar dan orang dewasa yang lebih berpengalaman dengan bahasa kedua tersebut, orang dewasa dalam hal ini bisa jadi adalah guru di dalam kelas tersebut ataupun orang yang telah memperoleh bahasa tersebut sebagai bahasa pertama (Native speaker).(Ghazali, 2013)

Tahap - tahap yang dialami oleh seorang anak dalam memperoleh bahasa kedua tentulah tidak bisa disamakan dengan proses alami yang dialami anak ketika memperoleh bahasa pertama yang mana telah mulai diperolehnya begitu terlahir kedunia. Namun jika mengacu pada pendapat pakar yang telah dijelaskan sebelumnya, maka orang dewasa yang dalam hal ini adalah guru yang mengelola kelas bahasa kedua itulah yang akan membuat anak yang mempelajari bahasa kedua itu dalam posisi tetap belajar bahasa atau sudah memasuki ranah pemerolehan bahasa.

Kedua hal ini sebenarnya satu, namun jika kelas yang dibangun dibuat komunikatif dan interaktif, maka tentunya akan menjadi suatu hal yang berbeda. Secara fitrah sebenarnya manusia telah dibekali sebuah alat yang disebut Chomsky dengan Language acquisition device. Sehingga apapun yang dipelajari sebenarnya akan lebih mudah untuk dimengerti berkat piranti tersebut.

Agar pembelajaran bahasa kedua yang sedang dilakukan oleh seorang anak dapat memiliki proses yang sama dengan pemerolehan bahasa maka hendaknya pengajar memperhatikan bagaimana proses alami manusia dalam memperoleh bahasa pertama, diantarnya adalah sebagai berikut:

Hendaknya kelas bahasa dimulai dengan mempekenalkan bunyi dari setiap kata 
Setelah pengenalan huruf dan bunyi yang dimiliki oleh huruf tersebut barulah anak diberikan kesempatan untuk dikenalkan kepada kata-kata dengan cara diperdengarkan kemudian anak akan diminta untuk menirukan

Setelah proses tersebut, mulailah percakapan sederhana dengan kata-kata yang telah dipelajari sebelumnya.

Ketiga tahapan tadi sebenarnya adalah tahapan sederhana yang penulis sadur dari ayat al-Qur'an Dan Allah mengeluarkan kamu dari perut ibumu dalam Keadaan tidak mengetahui sesuatupun, dan Dia memberi kamu pendengaran, penglihatan dan hati, agar kamu bersyukur" (Qs. An-Nahl : 78)

Dari ayat ini sebenarnya Allah telah memberikan karunia kepada manusia pertama kali untuk memiliki kemampuan menyimak, lalu kemudian melihat untuk kemudian difahami. Ayat ini menjelaskan bahwasanya bagi pembelajar pemula bahasa kedua tidak harus dibebankan ribuan kaidah yang memberatkannya sehingga hilang minat dan motivasinya, namun sebaiknya kelas pemula diberikan kesempatan untuk mendengar kemudian menirukan apa yang telah dia dengarkan sebelumnya.

Setelah diberikan kesempatan untuk menyimak dan menirukan kedalam percakapan interaktif antara pengajar dan pembelajar, maka anak akan diberikan ruang untuk mengenal lebih lanjut kaidah dan makna yang terkandung dalam teks tertulis untuk kemudian akan diceritakan dengan kalimat tertulis kembali.

Dari uraian diatas, dapat dilihat bahwasanya pemerolehan bahasa kedua haruslah dibentuk sesuai dengan bakat bawaan manusia yang sudah dikaruniakan Allah kepada ummatNya. Dengan bakat natural tersebut, maka sudah selayaknya pembelajaran tidak hanya akan berakhir pada hafalan kosa kata dan kaidah semata tapi juga aktualisasi diri dalam menggunakan bahasa arab sebagai bahasa kedua di lingkungan artificial yang telah direkayasa secara bersama-sama antara pengajar dan pembelajar bahasa arab.

\section{HASIL DAN PEMBAHASAN}

Peluang pemerolehan Bahasa Arab sebagai bahasa kedua 
Indonesia sekarang ini belumlah mampu dikatakan untuk bisa menjadikan bahasa arab sebagai bahasa kedua. namun usaha pengembangan bahasa arab untuk terus diakui di Negara ini akan senantiasa ada. Pembelajaran bahasa arab dapat memasuki ranah pemerolehan bahasa jika pembelajaran tersebut bisa mengoptimalkan pembelajaran di dalam lingkungan keseharian siswa, dalam hal ini disebut dengan lingkungan berbahasa.

Lingkungan berbahasa merupakan sebuah wadah multifungsi yang bisa membuat siswa mempraktekkan langsung bahsa yang telah mereka pelajari di kelas, seorang anak yang terbiasa berbicara bahsa arab sehari-hari cendrung lebih mudah mengingat dan memahami makna dari apa yang telah mereka pelajari sebelumnya .

Lingkungan berbahasa yang mampu mendukung pemerolehan bahasa setidaknya diklasifikasikan kedalam dua jenis yaitu lingkungan bahasa formal dan lingkungan bahasa non formal. Dalam lingkungan bahasa formal pembelajar diperkenalkan secara sadar tentang bagaimana sifat dan bentuk asli dari kata tersebut lalu bagaimana cara menggunakannya dalam keseharian. Selain itu lingkungan juga harus didukung oleh beberapa media yang bisa membuat pembelajar termotivasi untuk bisa mencari tahu terkait materi yang sedang didalami oleh pembelajar seperti:

Pengajar mempersilapkan benda-benda yang memvisualkan kata tersebut dalam bahsa arab.

Pengajar menyediakan laboratorium khusus bahasa yang bisa digunakan untuk menggunakan bahasa arab secara formal

Pengajar menyediakan buku-buku berbahasa arab yang bisa diakses oleh pembelajar ketika mereka membutuhkan referensi terkait materi pembelajaran

Pengajar menyediakan audio berbahasa arab yang diproduksi oleh Penutur asli bahasa Arab, sehingga pembelajar mampu untuk mengolah data bahasa yang sedang mereka pahami.

Pengajar memberikan kesempatan kepada pembelajar untuk berinteraksi dengan native speaker bahasa arab (Rizqi, 2016) 
Selain lingkungan formal, pembelajar bahasa juga wajib memperoleh lingkungan informal, dimana pembelajar bisa secara totalitas menggunakan bahasa arab dengan teman, dan guru yang berada di lingkungan tersebut.

Dengan adanya lingkungan bahasa arab di kelas bahasa kedua, maka pembelajaran bahasa kedua sebenarnya bisa saja menjadi pemerolehan bahasa arab selayaknya pemerolehan bahasa pertama yang telah dikuasi oleh pembelajar sebelumnya.

Tantangan Pemerolehan Bahasa Arab sebagai bahasa kedua

Dalam proses pemerolehan bahasa kedua yang tidak selalu bisa disamakan dengan pemerolehan bahasa pertama setidaknya pembelajar akan mengalami sebuah fase yang disebut dengan bahasa antara. Bahasa antara yang dimaksud disini adalah bahasa kedua yang digunakan oleh pembelajar namun menyerupai system bahasa pertama yang telah dia kuasi sebelumnya. (Ainin, 2010)

Hal ini tentunya disebabakan oleh belum sempurnanya pengetahuan dan kesempatan pembelajar untuk bisa mengekplorasi bahasa kedua sebagai bahasa yang akan digunakan dalam keseharian pembelajar. Adapun tantangan yang harus dihadapi oleh seorang pembelajar ketika sedang berada di kelas bahasa adalah

Proses interferensi bahasa yang masa dari proses tersebut berbeda-beda sesuai dengan lingkungan bahasa formal dan non formal yang dia ikuti

Adanya perbedaan yang cukup signifikan antara bahasa pertama dan bahasa kedua. Bahasa Indonesia merupakan rumpun bahasa yang beraglunitasi (bahasa yang terdiri dari akar kata dan imbuha, tapi akar kata dan imbuhannya jelas) sedangkan bahasa arab merupakan bahasa yang berinfleksi (satu kata tunggal memiliki banyak arti tapi tidak bisa digunakan untuk membedakan bagian dari kata yang lainnya)(Ainin, 2010)

Kedua tantangan ini senantiasa hadir dalam proses pembelajaran bahasa kedua. Adapun sebagai akibat dari kedua gejala tersebut (walaupun sudah berada pada sebuah lingkungan bahasa formal dan non formal) akan muncul beberapa kata, frase dan kalimat yang telah dikumpulkan oleh Zaini sebagai hasil analisisnya pada pola bahasa yang muncul dari proses berbahasa Arab(Zaini, 2013): 
Tabel1: Perubahan kata, frase, dan kalimat dalam proses berbahasa

\begin{tabular}{|c|c|c|}
\hline $\begin{array}{l}\text { Jenis } \\
\text { Perubahan }\end{array}$ & Bentuk Perubahan & Perubahan \\
\hline \multirow[t]{7}{*}{$\begin{array}{l}\text { Perubahan } \\
\text { bentuk kata }\end{array}$} & Perubahan masdar menjadi verba & أنت صناع مضحك، نعم؟ \\
\hline & Perubahan mashdar menjadi isim fa'il & تعب جدا أنا \\
\hline & Penyempitan mpeakna & إنسانه كبير كبير كمن \\
\hline & Perubahan kata tunjuk & ذلكه فاسد \\
\hline & $\begin{array}{l}\text { Pembentukan makna baru dengan } \\
\text { asosiasi }\end{array}$ & أنت ثقة جدا \\
\hline & $\begin{array}{l}\text { Perubahan isim fail menjadi isim } \\
\text { maf'ul }\end{array}$ & في البارحة أنا مصاب \\
\hline & $\begin{array}{l}\text { Perubahan isim maful menjadi isim } \\
\text { fa'il }\end{array}$ & هو ذلك غير مغهوم \\
\hline \multirow[t]{4}{*}{ Frasa } & Frasa nominal & أنا فقط \\
\hline & Frasa Verbal & خلاص يذهب لما؟ \\
\hline & Frasa Keterangan & أنت في أين أنقا ليل؟ \\
\hline & Frasa Depan & أنت إلينا؟ \\
\hline \multirow[t]{7}{*}{ Kalimat } & Penggunaan unsur asing & لا تكن مثل ذلك لاه ! \\
\hline & Pemilihan diksi yang tidak tepat & مصباحه يكوت \\
\hline & Penghilangan unsur kalimat & مريض لا؟ \\
\hline & Penambahan unsur kalimat & متى متى نحن نأكل معا؟ \\
\hline & Perubahan struktur kalimat & أنت شراء ماذا؟ \\
\hline & $\begin{array}{l}\text { Aspektualitas dalam penggunaan } \\
\text { verba }\end{array}$ & منذ متى أنت ترجع؟ \\
\hline & Ketidaksesuaian antar unsur & تيئس أنا \\
\hline
\end{tabular}

Jika dilihat dari pola-pola yang ditemukan oleh Zaini diatas, maka dapat kita tarik kesimpulan bahwasanya bahasa yang digunakan oleh pembelajar yang memiliki lingkungan informal seperti Pondok Darussalam pun masih memiliki 
kesalahan dalam proses bahasa tersebut. Kesalahan ini sebagaimana Brown yang dikutip oleh Ainin bersumber dari tiga elemen yaitu kesalahan interlingual transfer, intralingual transfer, kesalahan dalam konteks pembelajaran (Ainin, 2010)

Kesalahan interlangual transfer adalah kesalahan yang disebabkan oleh adanya "campur tangan" system bahasa pertama kedalam aturan bahasa yang kedua. Misalnya mata-mata nahnu nakkul ma'an. Penggunaan kalimat "mata-mata" dalam kalimat ini adalah penggunaan kebiasaan dari bahasa Indonesia yang sering kali mengucapkan kata kapan dengan kapan-kapan, bukan dengan maksud bertanya tapi hanya sekedar memberikan pengharapan akan terjadinya hal tersebut "nakkul ma'an".

Kesalahan yang kedua yaitu kesalahan intralingual transfer, kesalahan ini disebabkan karena pembelajar belum memahami dengan baik pola kaidah yang dimiliki oleh bahasa arab dan akhirnya dia akan memilih kaidah lain yang telah ia fahami, misalnya "anta shina' mudhik". Pada kalimat ini, pembelajar menggunakan kata shina' dan bukan kata kerjanya. Pembelajar cendrung menyamakan mashdar dan kata kerja yang pada bahasa arab memiliki tugas dan fungsi yang berbeda.

Kesalahan yang ketiga adalah kesalahan yang bersumber pada proses pembelajaran bahasa arab berlangsung, baik dari segi materi, metode, dan segala hal yang terkait pembelajaran. Misalnya pada kalimat "la takun mitsla dzalik laah", terdapat kata "lah" dalam kalimat bahasa arab yang mana kata tersebut berasal dari kata bahasa Indonesia. Kata lah sering kali diucapkan oleh beberapa pengajar yang tanpa sengaja membawa serta kata tersebut dalam pembelajar, dan hal tersebutlah yang akan tertanam dalam benak pembelajar untuk kemudian secara sadar ketika berbicara bahasa arab.

\section{SIMPULAN}

Dari uraian diatas dapat disimpulkan bahwasanya pemerolehan bahasa arab di kelas bahasa kedua bisa dilakukan dengan beberapa peluang dan tantangan yang ada. Peluang yang dimiliki oleh Pembelajar adalah ketika Pengajar dan orang dewasa lainnya yang telah lebih dahulu mempelajari bahasa kedua tersebut, secara bersama-sama membuat sebuah lingkungan berbahasa buatan, yang nantinya bisa digunakan secara bersama-sama dengan pembelajar, sehingga pembelajar tidak 
hanya mendapatkan ilmu bahasa, tapi juga mampu menggunakan bahasa baik secara fonetik, semantic, sintaksis hingga morfologinya.

Adapun tantangan yang pasti akan dihadapi oleh pembelajar bahasa arab sebagai bahasa kedua adalah adanya perbedaan kaidah kebahasaan yang dimiliki oleh bahasa Arab dengan bahasa Indonesia sehingga tentunya akan memunculkan kesulitan tersendiri jika tidak segera diatasi. Tantangan berikutnya adalah kecendrungan Pembelajar untuk membawa serta pengalaman bahasa pertamanya ke dalam proses berbahasa Arab, sehingga memunculkan kata, frase, dan kalimat yang tidak beraturan dan cendrung berupa bahasa Indonesia yang diarabkan bukan bahasa arab yang sebenarnya ada. Proses tersebut dinamakan proses bahasa antara yang mana setiap orang akan melaluinya dan kemudian akan berakhir pada waktu yang tidak sama, karena proses bahasa antara melibatkan secara optimal baik dari pemerolehan hingga pembelajaran, anak yang cendrung mempelajari kesalahan dalam prosesnya berbahasa akan lebih cepat menyelesaikan masa tersebut dibanding dengan anak yang tidak menyadari kesalahan berbahasanya.

\section{DAFTAR PUSTAKA}

Ainin, M. (2010). Analisa Bahasa Pembelajar Bahasa Arab sebagai Bahasa Asing. Malang: Misykat.

Anshari, M. (n.d.). Akuisisi bahasa arab pada tataran gramatika dan rasa bahasa bagi pembelajar non arab.

Chaer, A. (2009). Psikolinguistik. Jakarta: Rineka Cipta.

Faiqoh, M. D. (2014). Pemerolehan Fonologi Bahasa Arab Anak Usia 12 tahun DI MTs Islam Ngruki Sukoharjo. CMES, VII.

Ghazali, A. S. (2013). Pemerolehan dan Pembelajaran Bahasa Kedua. Malang: Bayu Media Publishing.

Hasanah, M. (2010). Proses Manusia Berbahasa. malang: UIN Press.

huda, nafiul. (2017). model pemerolehan bahasa arab sebagai bahsaa asing pada peserta didik non native speaker. Nidhomul Haq, 2, 95-105.

Rizqi, M. R. (2016). Peran Bi'ah Lughowiyyah dalam meningkatkan pemerolehan bahasa arab. Alfazuna, 1(1), 129. 
Thonthowi, T. (2015). Bi'Ah Arabiyah Dan Pemerolehan Bahasa. LiNGUA: Jurnal Ilmu Bahasa Dan Sastra, 2(2), 30-43. https://doi.org/10.18860/ling.v2i2.565

Zaini, H. (2013). Bahasa Arab Khas Gontor. Yogyakarta: Bunyan. 